\title{
HISTORICAL DEVELOPMENT OF BEE FORAGING PATTERNS IN CENTRAL NEW YORK STATE
}

\author{
By Howard S. GinsberG* \\ Department of Entomology \\ Cornell University \\ Ithaca, New York 14853
}

\begin{abstract}
INTRODUCTION
The bee fauna of the northeastern United States has changed markedly in the past few centuries. The impetus for this change came largely from human activities, notably from introductions of foreign species and modifications of the regional flora. Several bee species, most notably the honey bee (Apis mellifera), were introduced into this region (Crane 1975; Linsley 1958). Honey bees can powerfully influence the foraging patterns of native bees (Pearson 1933; Eickwort and Ginsberg 1980). Replacement of forests over large areas by cities and farms (Ferguson and Mayer 1970; Vaughan 1929) and numerous introductions of alien plant species (Wiegand and Eames 1925) have resulted in major changes in northeastern plant communities.

How broad were these changes and how have they influenced the foraging ecology of northeastern bees? What was this area like before the European settlers arrived? The answers to these questions are vital to an understanding of contemporary bee foraging patterns and of community level interactions between flowers and their pollinators. The purpose of this paper is to describe some general trends in the foraging patterns of Apoidea in central New York State, and to interpret them in terms of the historical development of the flora and bee fauna of the region.
\end{abstract}

\section{Materials AND MethodS}

The study site was a 5.8 hectare abandoned field (last cultivated about 1956) located near Ithaca, New York. It was bordered by

\footnotetext{
*Present Address: Department of Ecology and Evolution, State University of New York at Stony Brook, Stony Brook, New York 11794 Manuscript received by the editor August 8, 1981
} 
wooded areas and cultivated fields. The soils were well-drained and flower bloom was profuse. More than 150 entomophilous species bloomed on the field. The most common woody plants were red maple (Acer rubrum), staghorn sumac (Rhus typhina), and various willows (Salix spp.), dogwoods (Cornus spp.), and brambles (Rubus spp.). The dominant herbaceous plants included several entomophilous species and the grasses timothy (Phleum pratense) and orchard grass (Dactylis glomerata).

I sampled Apoidea by walking transects and capturing bees from flowers. There were $10,30 \mathrm{~m}$ transects randomly-placed on the field. I took transect samples during times of maximum foraging activity (1000-1600 hours) throughout the season (at least 3 samples in each 2-week period, late May-October, 1974 and 1975). I used all-day samples from randomly-selected patches of common flower species (throughout the growing season, 1975 and 1976) to confirm the results from the transect samples and to study spatial distributions of foraging bees. Voucher specimens of the bee species are placed in the Cornell University Insect Collection, lot number 1039.

I counted the number of flowers of each species at anthesis in 100, $1 \mathrm{~m}^{2}$ subquadrats. The subquadrats were arranged in groups of 10 , randomly-placed within $30 \mathrm{~m} \times 30 \mathrm{~m}$ quadrats (the bee transects were also within these quadrats). There were 10 quadrats randomlyplaced on the field. Flowers were sampled once every 2 weeks throughout the season. Voucher specimens of the plant species are placed in the Bailey Hortorium Herbarium, Cornell University. Details of the field techniques are given by Ginsberg (1979).

I used the records of Fernald (1950) and Wiegand and Eames (1925) to determine whether flower species were native or were introduced into the area. Their determinations were based largely on the records of early botanical explorers (e.g. Pursh 1923) and on previous species lists for the area (e.g. Dudley 1886). Admittedly, there is some margin for error in these judgements, but because of the large number of entomophilous species on the sample site, mistakes about the points of origin of a few species should not influence the major arguments.

\section{RESULTS}

Red maple was the first abundant flower species to bloom on the field in spring. Several willows and rosaceous trees (Prunus cerasus, 
Pyrus malus) bloomed soon after, as did several roadside weeds such as dandelion (Taraxacum officinale) and yellow rocket (Barbarea vulgaris). The spring species were typically clustered in distribution at roadsides and forest edges, and the woody species had relatively short blooming times. Of 16 species recorded on the field in spring (late April and early May in 1975) half were native and half were introduced. I do not include any of the several species that bloomed in the woods nearby.

Flower bloom increased on the field to a maximum in early summer (late June, early July). Most of the species in bloom at this time of the year were introduced (Fig. 1). Table I lists the most common of these species and gives their frequencies of occurrence in the subquadrats. Note that the most common flowers at this time were those of introduced herbaceous species. Most flowers of these species were past blooming by midsummer.

In August, goldenrods (Solidago spp.) predominated on the field. These late summer flowers are native to this region (Table I). Aster, another native genus of composites, predominated after goldenrod passed bloom in the fall. Late season flowers, therefore, were mostly native species (Fig. 1).

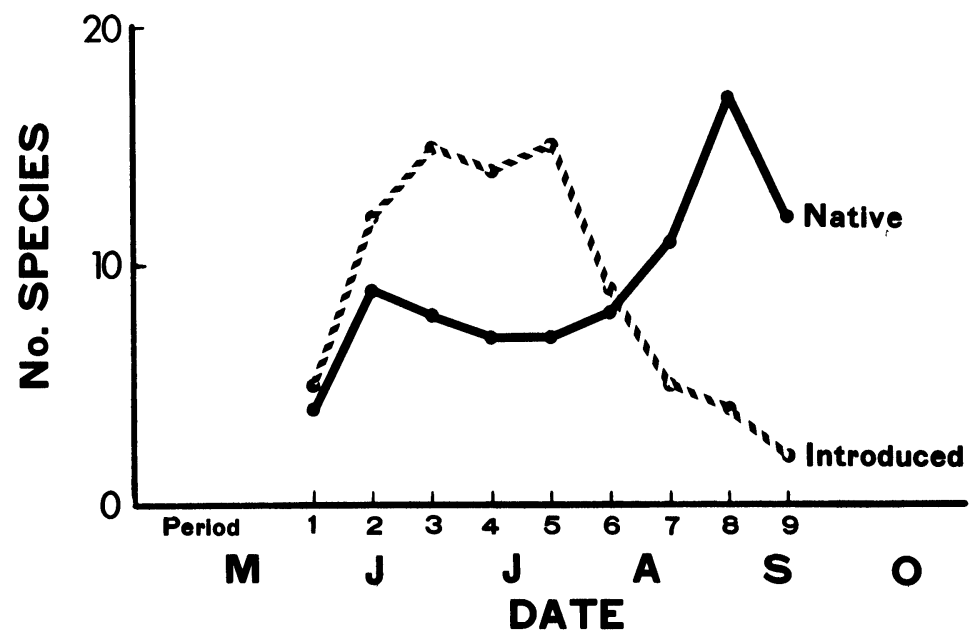

Fig. 1. Number of introduced and native flower species blooming over the summer, 1974, in an old field near Ithaca, New York. 
Table I. Frequencies of common flower species, 1974

\begin{tabular}{lcccc} 
Flower species & Origin ${ }^{1}$ & $\begin{array}{c}\text { Time of } \\
\text { maximum } \\
\text { bloom }\end{array}$ & Frequency ${ }^{2}$ & $\begin{array}{c}\text { No. } \\
\text { inflores- } \\
\text { cences } / \mathrm{m}^{23}\end{array}$ \\
\hline $\begin{array}{l}\text { Hieracium pratense } \\
\begin{array}{l}\text { Chrysanthemum } \\
\text { leucanthemum }\end{array}\end{array}$ & $\mathrm{I}$ & mid June & 70 & $12.55 \pm 2.06$ \\
$\begin{array}{l}\text { Cornus racemosa } \\
\text { Satureja vulgaris }\end{array}$ & $\mathrm{I}$ & late June & 54 & $2.21 \pm 0.32$ \\
Achillea millefolium & $\mathrm{N}$ & late June & 12 & $2.10 \pm 1.10$ \\
Daucus carota & $\mathrm{N}$ & late July & 30 & $12.11 \pm 3.08$ \\
Solidago juncea & $\mathrm{I}$ & late August & 20 & $1.04 \pm 0.34$ \\
S. graminifolia & $\mathrm{N}$ & late August & 30 & $0.87 \pm 0.20$ \\
S. rugosa & $\mathrm{N}$ & late August & 60 & $12.86 \pm 2.08$ \\
S. altissima & $\mathrm{N}$ & early Sept. & 54 & $9.16 \pm 1.85$ \\
\hline
\end{tabular}

$1 \mathrm{~N}=$ native species; $\mathrm{I}=$ introduced species

2 Number of $1 \mathrm{~m}^{2}$ subquadrats (out of 100) in which species was flowering during period of maximum bloom.

3 Mean number of inflorescences (sprays for Solidago) per subquadrat during period of maximum bloom \pm standard error.

This flowering trend of early-summer introduced species and latesummer-fall native spẹcies probably holds for central New York as a whole. In Figure 2 I plotted the number of open-habitat, entomophilous species blooming in the entire Cayuga Lake Basin during each 2-week period over the season (compiled from Wiegand and Eames 1925). Again, introduced species predominate in early summer. Later in the summer, native and introduced species are about equal in number, but the tremendous abundance of goldenrod (Table I; also Ginsberg 1979, Hurlbert 1970) results in a preponderance of native flowers late in the season.

Foraging phenologies of the most common bee species indicate a partitioning of the season according to foraging times. Native wild bees (mostly primitively social halictines) predominated in early summer, while Apis mellifera predominated in late summer (Table II). This presents the interesting situation that native bees foraged primarily on introduced flowers in early summer, while the introduced honey bees foraged on native flowers in late summer and fall (Table III). 


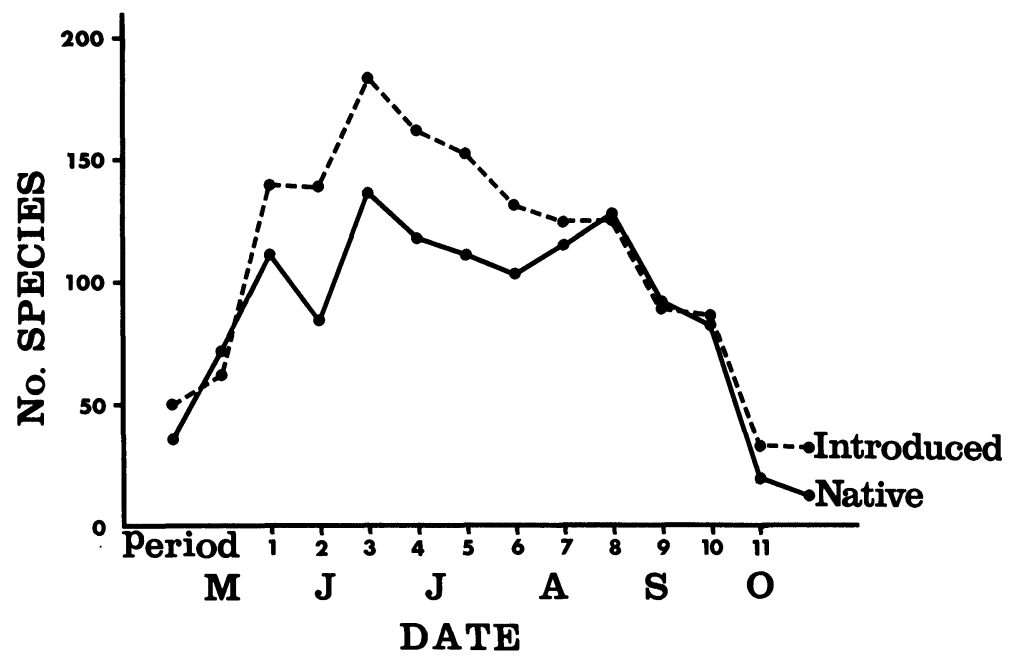

Fig. 2. Number of introduced and native flower species blooming in the Cayuga Lake Basin (compiled from Wiegand and Eames 1925).

Table II. Percent of honey bees in transect samples, 1974

\begin{tabular}{clcr} 
Period & \multicolumn{1}{c}{ Dates } & \% honey bees 1 & $N$ \\
\hline 1 & 22 May-4 June & 2.1 & 48 \\
2 & 5 June-18 June & 1.9 & 52 \\
3 & 19 June-2 July & 9.0 & 67 \\
4 & 3 July-16 July & 7.6 & 79 \\
5 & 17 July-30 July & 13.8 & 29 \\
6 & 31 July-13 August & 15.9 & 44 \\
7 & 14 Aug-27 August & 79.8 & 119 \\
8 & 28 Aug-10 September & 95.2 & 230 \\
9 & 11 Sept.-24 Sept. & 89.7 & 78 \\
\hline
\end{tabular}

1 Percent of bees captured in transect samples that were Apis mellifera. Other bees in these samples were native wild bees (except for 3 individuals of Andrena wilkella captured on 28 May, 12 June, and 8 July-this species was probably introduced into the region). 
Table III. Flower species most commonly visited by bees during the summer, 1974

\begin{tabular}{|c|c|c|c|}
\hline Bee species ${ }^{1}$ & Flower species ${ }^{1}$ & $\%$ of visits $^{2}$ & sample size ${ }^{3}$ \\
\hline Apis mellifera (I) & $\begin{array}{l}\text { Solidago altissima }(\mathrm{N}) \\
\text { S. graminifolia }(\mathrm{N}) \\
\text { S. juncea }(\mathrm{N})\end{array}$ & $\begin{array}{l}26.2 \\
24.0 \\
18.8\end{array}$ & 409 \\
\hline Ceratina $^{4}(\mathrm{~N})$ & Rubus allegheniensis $(\mathrm{N})$ & 28.0 & 50 \\
\hline Halictus ligatus $(\mathrm{N})$ & $\begin{array}{l}\text { Chrysanthemum leucan- } \\
\text { themum (I) }\end{array}$ & 51.2 & 43 \\
\hline Halictus confusus $(\mathrm{N})$ & Potentilla recta (I) & 47.6 & 21 \\
\hline Auguchlorella striata $(\mathrm{N})$ & $\begin{array}{l}\text { Chrysanthemum leucan- } \\
\text { themum (I) }\end{array}$ & 37.5 & 24 \\
\hline Dialictus rohweri $(\mathrm{N})$ & Potentilla recta $(\mathrm{I})$ & 47.4 & 19 \\
\hline
\end{tabular}

1 Point of origin given in parentheses; $N=$ native to North America; $I=$ introduced.

2 Percent of individuals of that bee species in samples that were on named flower species.

3 Number of bees of that species in transect samples, 1974.

${ }^{4}$ Includes Ceratina dupla and C. calcarata. Females of these species are indistinguishable at present.

Spring-flying bees were not included in Table II because they foraged on flowers that were most common off the field and could not be sampled by the transect technique. All-day samples from patches of common spring flowers revealed a great diversity of native bees, primarily solitary, univoltine species of Andrena, Dialictus, and Ceratina. Honey bees were also common in spring, especially on willows, rosaceous trees, and on large clusters of dandelion and yellow rocket.

\section{Discussion}

The fact that native bees foraged on introduced flowers in early. summer, while introduced bees predominated on native flowers in late summer, suggests that this type of old field association is quite recent in origin. Indeed, the development of this curious pattern can be clarified by tracing the recent biotic history of the Ithaca area.

Early explorers in the region (up until the early 1800's) reported extensive forested areas that were thickest near the head of Cayuga Lake and to the south of Ithaca (Dudley 1886). The Indians cleared considerable acreages for villages, corn fields, etc. (Day 1953) and kept corridors of land clear for stalking deer by annual burning 
(Dudley 1886). These cleared areas were probably far less extensive than present-day open habitats. Also, the deer-stalking grounds differed from modern old fields because they were burned each year, and because they lacked many of the introduced flower species that are now common. Some of these species were introduced by 1807 , when the explorer Frederick Pursh passed through Ithaca (Dudley 1886; Pursh 1923).

The first settlers arrived in Ithaca about 1789 (Dudley 1886). By the mid 1800's extensive areas of land had been cleared for farming and settlements. Total acreage used for farming reached a peak in New York State (approximately 23,780,754 acres) about 1880 . Since then, gradual abandonment of farmland has given rise to many abandoned fields. By 1925, only 19,269,926 acres of farmland remained (Vaughan 1929). By the late 1960's the area of crop and pasture land in New York State totalled only about 8,771,800 acres (Ferguson and Mayer 1970). Much of this farm land was lost to villages and cities, but a considerable amount was left as abandoned fields. In the late 1800 's and early 1900 's several weedy species were introduced, and many others increased in abundance in central New York. Among the species that became common at this time were Hieracium pratense and Potentilla recta (Wiegand and Eames 1925), both important species at my sample site (Tables I and III). Taken together, these facts suggest that the current floral composition of old-field communities in central New York is on the order of 100 years old.

As a result of these changes in the local flora, at least three new classes of abundant flower forage have become available to bees. In spring, the introduced rosaceous trees and roadside weeds provide considerable forage. Second, the increased acreage of abandoned fields, along with introductions of several plant species, results in an historically novel flower bloom in early summer. Finally, the large acreage of open fields results in an unprecedented profuse bloom of goldenrod in late summer.

The honey bee was introduced into North America by the early colonists (Crane 1975). The Italian strain (Apis mellifera ligustica), which now predominates in New York State, was not introduced until 1859 (Ruttner 1975). Some more recent introductions into the Ithaca area include the megachilids Megachile rotundata (Mitchell 1962) and Anthidium manicatum (Pechuman 1967), and the andre- 
nid Andrena wilkella (Linsley 1958). At my study site, the honey bee is far the most abundant of these species (Ginsberg 1979). In the 1950's, honey bee populations declined sharply in New York State due to the increased use of pesticides and the decline in farm acreage devoted to buckwheat, an important food source for honey bees (Morse 1975). Before 1950, therefore, honey bees were even more common than at present.

Apis mellifera is a high-density specialist in flower foraging. Its large colony size and recruitment capabilities facilitate this specialization (Eickwort and Ginsberg 1980; Sakagami 1959). In spring, honey bees forage on high-density resources such as rosaceous trees, willows, and clusters of roadside herbs. In late summer, honey bees forage on the super-abundant goldenrods, also high-density resources.

In early summer, honey bees are relatively rare on the old field (Table II). At this time of season they forage primarily off the field on high-density resource species in forests and on cultivated fields (Farrar 1944; Ginsberg 1979). The introduced herbs that bloom at this time are exploited by primitively social halictines (Table III). The multivoltine seasonal cycles of these bees allow them to build up their populations over the season, thus they can exploit the recently introduced flower species that are now abundant in early summer. Ceratina, which is probably univoltine in the Ithaca area, is also common in early summer, but it forages somewhat earlier than the halictine bees, and is most common on native flowers such as Rubus spp. (Table III).

An interesting result of this analysis is that each of the major historically novel instances of resource abundance is exploited by social bees. Honey bees forage on rosaceous trees and roadside weeds in spring, and on goldenrods in late summer. Native bees forage on these flowers also, but honey bees predominate because of their high populations and recruitment ability, both features related to their social behavior. Social halictines predominate on introduced herbs in early summer because of their broad host ranges and their multivoltine seasonal cycles, also related to their sociality. Apparently, the ability to adapt to landscape-level changes in resource availability is an important advantage that accompanies social behavior in bees. This does not mean that only social insect species can adapt rapidly to changes in resource levels. It does suggest that in bees, sociality facilitates this rapid adaptability. 


\section{ConClusions}

In an abandoned field in central New York State, native bees foraged predominantly on introduced flower species in early summer, while the introduced honey bee predominated on native goldenrods in late summer. This situation results from recent changes in the flora and fauna of the region.

The activities of European settlers have caused large-scale changes in the flora of the northeastern United States. These changes result primarily from introductions of alien species, and from clearing of land for farming with subsequent abandonment. At present, there are at least three instances of profuse flowering over the season that are historically novel to this area. These are the abundant bloom of introduced trees and roadside weeds in spring, the flowering peak of introduced weeds in early summer, and the profuse flowering of native goldenrods in late summer. In all three of these cases, the predominant foragers are social bees; honey bees in spring and late summer, and social halictines in early summer. The ability of these bees to exploit historically novel pulses of flowering results from features related to their social behavior; large colony size and recruitment ability in Apis mellifera, and the multivoltine seasonal cycle in the social halictines.

\section{ACKNOWLEDGMENTS}

I thank G. C. Eickwort, F. C. Evans, R. A. Morse, and R. Nowogrodzki for constructive comments on early drafts of the manuscript. F. J. Rohlf provided useful advice. I also thank W. Denison and family for providing their land as a study site. This study was conducted in partial fulfillment of the requirements for the Doctor of Philosophy at Cornell University. Funding was provided, in part, by NSF grant no. BMS-72-02386 to G. C. Eickwort.

\section{Literature Cited}

Crane, E.

1975. The world's beekeeping—past and present. In Dadant and sons (eds.) The Hive and the Honeybee. Hamilton, Ill.: Dadant and sons, pp. 19-38. DAY, G. M.

1953. The Indian as an ecological factor in the northeastern forest. Ecology 34:329-346. 
DUDLEY, W. R.

1886. The Cayuga flora. Bull. Cornell Univ. (Science) 2:1-132.

EIcKworT, G. C. AND H. S. GinsBerg

1980. Foraging and mating behavior in Apoidea. Ann. Rev. Entomol. 25:421446.

FARRAR, C. L.

1944. Productive management of honeybee colonies in the northern states. USDA circ. No. 702.28 pp.

Ferguson, R. H. ANd C. E. Mayer

1970. The timber resources of New York. USDA Forest Service Resource Bull. NE-20, 193 pp.

Fernald, M. L.

1950. Gray's Manual of Botany. 8th ed. New York: D. Van Nostrand. 1632 pp.

GINSBERG, H. S.

1979. Foraging ecology of pollen utilizing insects on an old field in central New York State. Ph.D. Thesis, Cornell Univ. Ithaca, N.Y. 221 pp.

HuRLBert, S. H.

1970. Flower number, flowering time, and reproductive isolation among ten species of Solidago (Compositae). Bull. Torrey Bot. Club 97:189-195.

LINSLEY, E. G.

1958. The ecology of solitary bees. Hilgardia 27:543-599.

Mitchell, T. B.

1962. Bees of the eastern United States, Vol. II. N. Carolina Agr. Exp. Sta., Tech. Bull. No. 152. 557 pp.

Morse, R. A.

1975. Bees and Beekeeping. Ithaca, N.Y.: Cornell Univ. Press. 295 pp.

Pearson, J. F. W.

1933. Studies on the ecological relations of bees in the Chicago region. Ecol. Monogr. 3:375-441.

Pechuman, L. L.

1967. Observations on the behavior of the bee Anthidium manicatum (L.). J. N. Y. Entomol. Soc. 2:68-73.

PURSh, F.

1923. Journal of a botanical excursion in the northeastern parts of the states of Pennsylvania and New York during the year 1807. Dehler Press. 113 pp.

RUTTNER, F.

1975. Races of bees. In Dadant and sons.(eds.) The Hive and the Honeybee. Hamilton, Ill.: Dadant and sons, pp. 19-38.

SAKAGAMI, S. F.

1959. Some interspecific relations between Japanese and European honeybees. J. Animal Ecol. 28:51-68.

VAughan, L. M.

1929. Abandoned farm areas in New York. Cornell Univ. Agr. Exp. Stat. Bull. 490:1-285.

Wiegand, K. M. AND A. J. Eames

1925. The flora of the Cayuga Lake Basin. Cornell Univ. Agr. Exp. Sta. Mem. 92:1-491. 

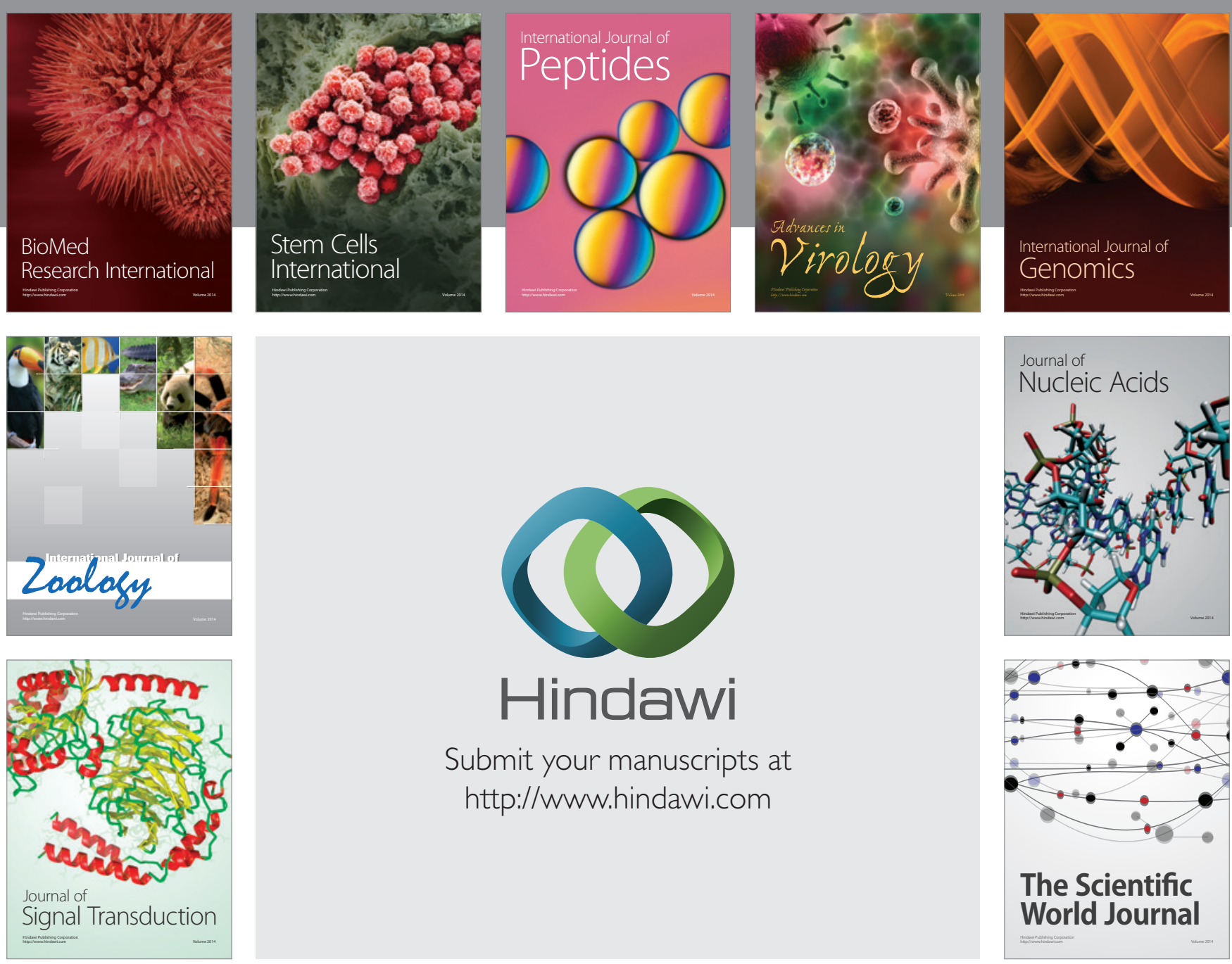

Submit your manuscripts at

http://www.hindawi.com
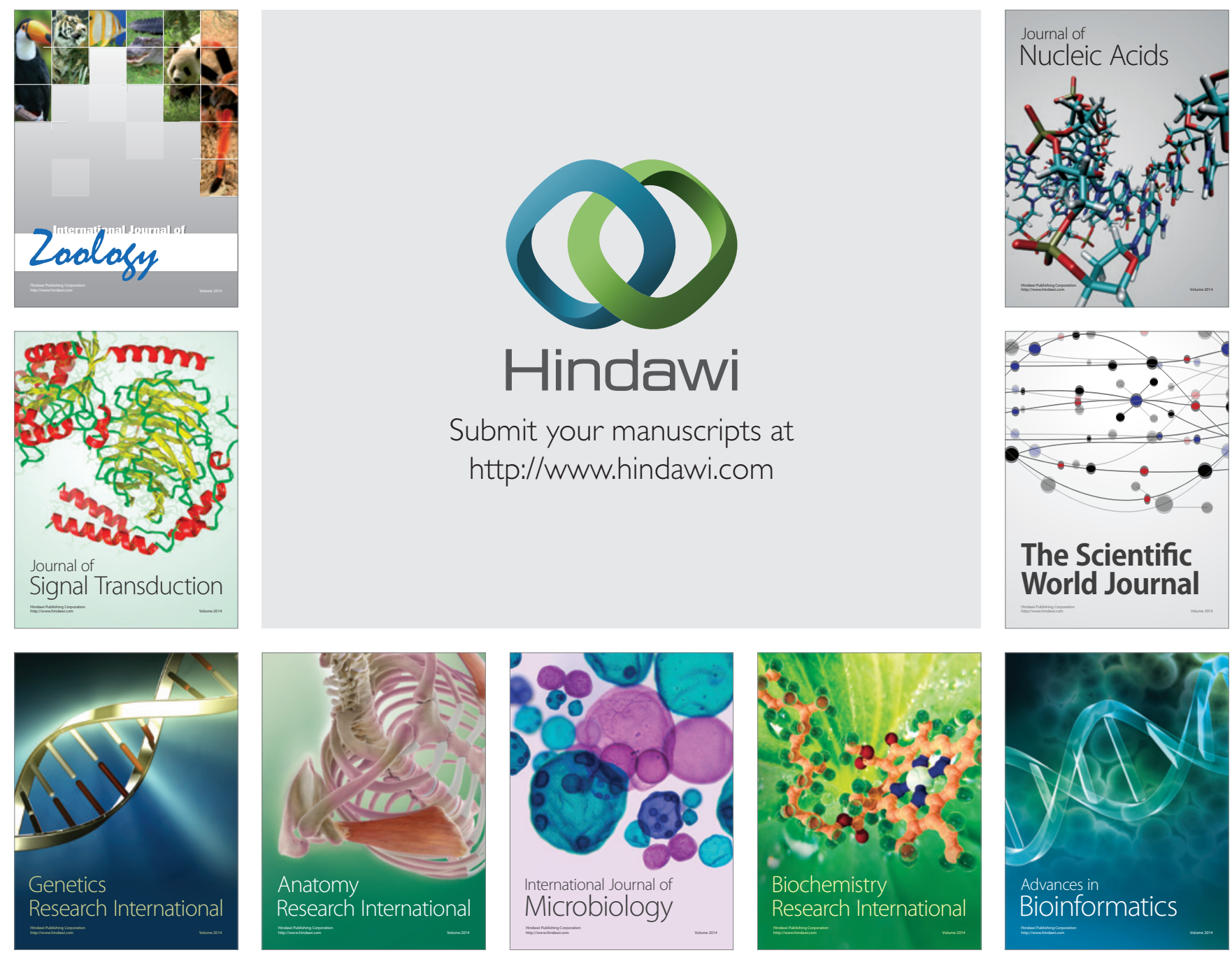

The Scientific World Journal
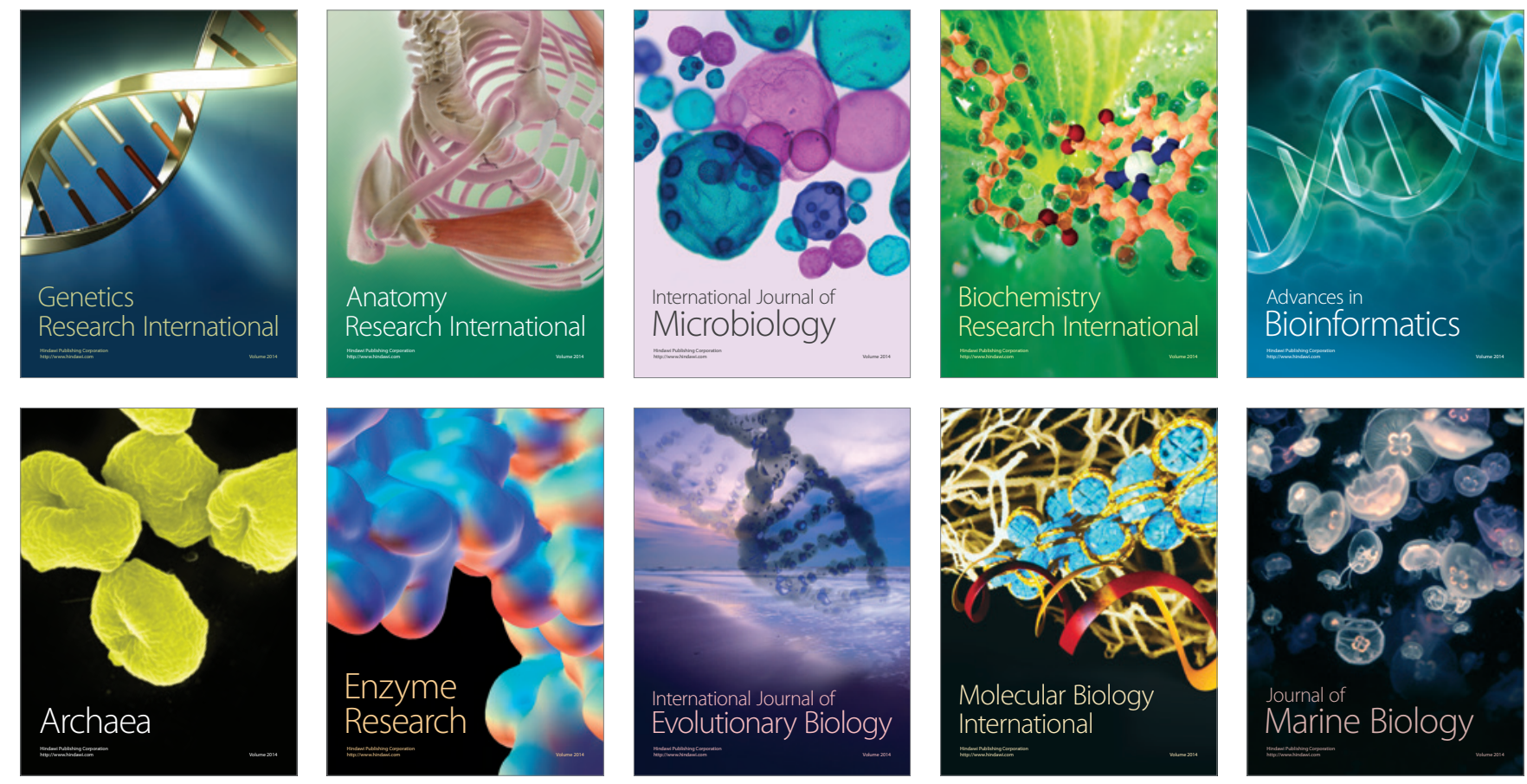